\title{
Towards Globalization of Criminal Legislation: French Criminal Legislation as a Model
}

\author{
Rana Atour \\ College of Law, University of Sharjah, UAE \& the University of Jordan, Amman, Jordan \\ Email address: \\ dr.ranaatour@yahoo.com

\section{To cite this article:} \\ Rana Atour. Towards Globalization of Criminal Legislation: French Criminal Legislation as a Model. International Journal of European \\ Studies. Vol. 3, No. 2, 2019, pp. 67-74. doi: 10.11648/j.ijes.20190302.11
}

Received: July 3, 2019; Accepted: July 26, 2019; Published: September 23, 2019

\begin{abstract}
Objectives: Globalization has been observed to produce new challenges of criminal justice, by creating new opportunities for transnational corporate crime in this era. Word is facing serious threats due to criminality issues. The concept of globalization has been observed to play a significant role in inspiring the global justice and international Law. This study has been carried out to evaluate the globalization of criminal legislation by considering the model of French legislation and penal code. Methods: Different articles have been taken into consideration from French penal code in order to perform a qualitative analysis, with respect to the criminal legislation and globalization. Results: Detailed analysis of literature state that an access is required towards comparative legislation, which provides an assurance about the respect of human rights. Conclusion: It has been examined through past studies that the European law regarding human rights constitutes a significant source of criminal law, to ensure respect for human rights. Globalisation is likely to lead a global harmonization of punitive legislations, by producing criminal principles respecting human rights, which can be applied to entire globe.
\end{abstract}

Keywords: Criminal Legislation, Penal Legislation, Globalization, European Law, Criminal Law

\section{Introduction}

The concept of globalization of law is an issue, which seems to embody numerous things to several types of people. According to the perspective of criminal law, it has been observed that globalization generally produces new challenges for the practitioners and researchers of criminal justice. Some of the most significant features of this change include the impact of legal and illegal immigration, international dimensions of crime, and technological influences on global criminality. The present decade shows a remarkable increase in global crimes, World is facing serious threats due to criminality issues.[31] The concept of globalization is not only associated with economy; however, it has also been observed to play a significant role in inspiring the global justice and international law. The globalization has been evaluated as having a strong impact on the abnormal behavior and thinking of criminals. This abnormality is generally reflected in the expansion of criminal acts, which seems to have a major contribution to the globalization of crimes. The national state is responsible for the implementation of its national crime legislations on almost all types of crimes, which usually occur within its political borders.[1] With respect to the penal law, it has been proposed by [9] that globalization is not likely to lead towards a global homogenization of penal practices and policies. The penal systems of 12 different countries have been classified on the basis of conservative corporatist, neoliberal, democratic, or oriental corporatist. This categorization has been observed to have a strong association with the punitiveness of penal culture.

In order to unify the criminal legislation, several attempts have been made during the two World Wars. Most of these attempts were associated with general issues, such as complicity and proceed, or about certain crimes concerning the rights of individuals, such as piracy, trafficking in women. Besides this, the International Union for penal law is required to preside over this movement, since 1926, many international conferences were held to pass the bills, according to the suggestions of future legislators. On the contrary, the movement was observed to be failed. This concept has been revived today on more modest foundations. Furthermore, talking about the harmony of punitive legislation, it seems to be more preferred, instead of uniting 
them. The economy of globalization and the legal norm globalization can be tackled by producing criminal principles by legal translational tools, which can be applied to entire globe. As it is recognized that criminal issues to be resolved at the global justice level to prevent World from collapsing [16].

\subsection{Problem of Unification of Rules of Criminal Law}

The European Council conventions are observed to give more preference to "harmonize national legislation". International court model organized in Europe, here domestic judges and international judges work together to generate legal rules [2]. Thus, there are many international conventions, ratified by the States to stunning convergence, and this convergence takes place on two levels [37]. Sometimes, the text is restricted to convention to take some particular texts by signatory States, which seems to be free in the formulation of words required. The same has justified in the case of International Convention against torture, which provides the states with "legislative measures to prevent the commission of acts of torture" in its territory. Moreover, according to article (222-1) of French Penal Code, the subjection of a person to the acts of barbarity or torture is punished by the criminal imprisonment for 15 years. Besides this, the European Convention has been held in Strasbourg regarding the transfer of convicted persons, during $21 / 03 / 1983$, which led before they have been placed under force. The date of law is $21 / 12 / 1984$, which has been added to the French criminal proceedings Substances Act (713-1) to (713-8). Besides this, the decision framed for the European Union of 13 June 2002, also required to be reminded on the basis of request that has been made by European arrest warrant. With respect to the law of transport on $09 / 03 / 2004$, another solution has been identified in relation to other decision frames for some crimes. On the other hand, when considering the convention text, it has been evaluated that this text sometimes goes beyond by drafting, which allows the signatory States to adopt it exactly in the same way. [21] This is a significant agreement of illegal Act (illicit ententes), which drafts semi-similar Article (85-1) related to the Rome Convention of 1957. The explanation about the freedom of competition and prices can be observed from Article 7 on the Decree of 1 December 1986. Target agreements (les ententes) are the themes or effect of prevention, restriction, or disrupt the procedure of competition, which is presented in Article (420-1) from French competition law. There is no doubt that the study of comparative law is very useful, which seems to emphasize on the efforts for the globalization or unification of penal legislation by considering international conventions.[38] The aim of writing for this topic is to evaluate the globalization of criminal legislation by acknowledging the French legislation model and the penal code.

\subsection{International Conventions}

When talking about the international conventions, a question arises. To answer this question, two different theories have been considered, i.e. the binary theory and theory of unit. According to the theory of duality, national and international law has considered as different legal systems, which seem to coexist side by side, but on an independent basis. Hence, national judge and the domestic law could not apply international law. The reason is that the application of international law by a national judge should be translated or transformed into the domestic law. In the case of contradiction among international sanctions and domestic law, the primary rule includes the applicability of law. [22]

On the other hand, the theory of unit is the law, under which a single unit comprises of the consistency of domestic law with international law. Hence, it seems to occur in the case of contradiction that the international law transcends it as a higher degree of internal law. Therefore, it has been assessed that the theory of unit has been adopted by French law, in Rome (25 March 1957), or the European Convention for the protection of human rights (4/11/1950). So, the French national judge monitors the compatibility of domestic laws with the Convention, despite not being able to monitor the constitutionality of laws, because of the Constitutional Council which performs the job. The modification of these instruments since 1950 and 1957 are required to be considered. The European Convention is observed to create the Rome Convention "Common Market" (EEC), which seems to be supplemented and amended through other important tools. The only contract, which entered into force on $1 / 7 / 1957$ and the Maastricht agreement signed on 7 February 1992, has been observed to transform the European Economic Community into the European Union. Finally, the Amsterdam agreement signed on $2 / 10 / 1997$ by amending the previous one, which entered into force on $1 / 5 / 1999$. For an explanation of the impact of international conventions on French penal code, two agreements are required to be emphasized, namely the Rome Convention, and European Convention on human rights. [23]

\section{Methodology}

As the study has been conducted to investigate the globalization of criminal legislation, the qualitative research approach has been adopted to examine the results. The data collection comprised of different articles, which have been stated under the French legislation and penal code. For the collection of appropriate data, numerous search engines have been selected, such as Google Scholar, ProQuest, and ScienceDirect. Moreover, the data collection has also been done through different journals and books, in which the French legislation articles have been discussed in detail.

\section{Results and Discussion}

As the impact of international conventions on French Penal Code is required to be observed, it is necessary to consider two different agreements. These agreements are Rome Convention and European Convention on Human 
Rights. Both of these agreements are discussed comprehensively in order to examine the impact of international conventions.

\subsection{Rome Convention and Related Accessories- European Collective Law [5, 8]}

At the first glance, it is possible to think that the Rome Convention has no concern with the Penal Code because no text has been included regarding the criminalization of punishment. In general, the group of European Court of Justice provides a confirmation which states that criminal legislation and rules of the procedure remains to be prerogative of Member States. This principle seems to be tentative so that the Penal Code and European Community Law exchanges significant relationships. On one hand, it has been observed that the European Community Law imposes on the obligations of individuals, such as drivers' lounge and deprives them of some things, for example, the fraudulent access to assistance. Since the European Community law does not provide criteria for sanctions, hence, it is necessary to respect its provisions. Furthermore, the basic freedoms have been established by the European collective law, such as freedom of passage for people, goods and services. Thus, these freedoms cannot be reduced by the countries, specifically through criminality in domestic legislation. This is the case in which the neutralization of National Penal Code by European law seems to be applied in the system unit, which in this case is complete within it. The searching of European collective law requires evaluating the mass violation of European texts on one hand before it determines the violation of national provisions. [30]

Contravention of European Collective.

For the discussion of violation of European collective texts, it is necessary to follow the tests of European collective statements and the role of national penal code.

\subsubsection{Concept of Collective European Texts}

Besides emanating from the Rome Convention itself, there is a "derivative law", which is composed of several forms of text with different values. Article (189) of Rome Convention comprised of the description of these rules. There is the beginning of system (the regulation), [12] which seems to be established by the Council of European Community, or by the Commission, that involves a year later, and is "binding in all its elements and directly applicable in each Member State". Moreover, the system seems to be directly applied to the states. It has been observed to exclude "all forms of implementation of the outcome of the immediate impact of disability on the system. And prevent it, and this is accompanied by a uniform system in total ACP". Since 1957, a large number of regulations are observed to be issued and published in the Official Gazette of Group. [34]

The recall from the Directive $[19,20]$ connects each Member State, which has been targeted for the accomplishment of results, leaving the jurisdiction of national courts for the form and methods. On a more modest level, a decision has been observed (The decision), [11] which is targeted for (whether people or company or Member State) contract "binding on all its elements". Finally, the recommendations are considered as free of all the mandatory power, which seems to be not associated in any way.

\subsubsection{The Role of National Penal Code}

An important principle of national penal code includes: the violation of a provision of Community law that has been derived, which does not constitute a criminal offense. Then, the act does not become a criminal unless punishable and criminalized by the domestic law, according to the discretion of national authorities, [41] whether in the field of criminality or in the penalty box.

\section{Criminalization}

Taking into consideration the criminalization, the impact of European collective criminality law is determined by decision maker criminality and the techniques of criminalization. In decision maker criminalization, the States consider itself as the only exclusive jurisdiction in the text on criminality, where the European Community law is limited to the formulation of a certain conduct. [15, 18] It has been pointed that "criminal texts punishment for the violation of collective texts are of the competence of States. Thus, offences against these rules cannot be prosecuted unless a provision in domestic law has been stated", Crim., June, 21, 1984.

With respect to the criminalization techniques, the legislator is sometimes required to consider the text, in order to create criminalization. This criminalization seems to preexist in a certain way. In this case, the internal text is sufficiently broad to include European collective command, [25] which is mentioned in Article (426) of the Customs Act that punishes false statements. The target or their effects get compensation, exemption, or a reduced right, or whatever advantage linked to the import or export. In France or any other foreign country, access without right as well as profit from the preferential system is observed to be provided in the Treaty or text in internal law. Furthermore, the cases in which collective law enshrines the analogy principle can also be included, provided that the acts had already criminalized in domestic law. [35]

In case, if there is no direct application of collective text guidance, it is the responsibility of national authorities to transfer the internal law, by means of text transport. Here, the community law builder demonstrates a positive influence, where the national legislature must create situations of criminalization, in the case if there are no collective rules. Taking into consideration the penalty of box, sometimes, the internal law provides for the transfer of penalty box at the same time. On the contrary, at other times, the internal text does not specify punishment, but refers to internal text of other former states. Thus, it has been assumed to be very adjacent.

The national States should provide data for the criminalization and Punishment Act, as prescribed in the collective law. The base of collective behavior can be "recopied" by the State in a national text and add a sanction 
for violation.[26] However, in most of the cases, the State resorted. For instance, DDR referral (integration par reference), under which the text has been provided by national authorities. This text is limited to the text on criminal penalty, which seems to be shown in the text and the practical situation. It has been proposed by Article 11 of the law of 1 August 1905 (today's article (L. 214-1) of the code of consumption), "it will be judged by the General management systems on measures taken to ensure the implementation of existing law." For a long time, these systems were observed to be internal and specific, such as the components of butter, honey, or cheese, or the labeling of such products. Hence, the collective systems have been observed to comprise of the same goals. The offences against collective regulations have been provided in the law of 1905 , which becomes a material (213-1 to 213-5) of French consumer law. [36]

\section{Penalty}

When a collective text is violated, the States alone provide the criminalization of cases, which also seems to be competent in stipulating penalties, which are owned by the commission [44]. However, the freedom of States is somewhat reduced by the Court of Justice of European Community, which establishes fundamental principles [6].

Principles restricting the Freedom of Legislator in the choice of Penalty - Fundamental Principles [39]

The first principle to the amount of penalty seems to be an actual application of collective rules. Moreover, the particular sanctions by the State must be severe enough to become "deterrent" - C. J. C. E., September 21, 1989-. The proportionality has been considered as the second principle, which matters at the time of nature and amount of penalty. Regarding the nature of penalty, the European Court of Justice ruled out the application of imprisonment, in connection with the directive of 15 October 1968 on free movement of workers. Hence, it has been observed the confinement was excluded from this area, arguing that "unjustified text, unbalanced penalty dramatically with the gravity of crime, which serves as an impediment in the freedom of employees - C. J. C. E., July 3, 1980-. The amount of penalty has also been counted by the principle. This is the case in connection with system, which imposes matinee time on street drivers. The EC Court of Justice recalls that "traffic safety is of public interest that would justify the imposition of a fine on the employer. Such an imposition is not unbalanced with the desired goal" - C. J. C. E., July 10, 1990.

\section{Compel the Legislature to choose the Box}

The absolute authority theory seems to be declined to some extent in the legislation, particularly with the decision of the Court of Justice of European Community on 13/9/2005, D. 2005.3046. The decision was that European Community can urge the Member States to adopt criminal penalties, when this will allow respecting the legislation. Furthermore, the Court has also been observed to go to the legislator, due to the reason that European Community can impose sanctions on environmental penalties legislation, C. $J$.

\section{E., October 23, 2007, R. P. D. P.}

Violation of National Texts. In some particular situations, the collective law seems deviate from national criminal rule. This neutralization seems to be applied specifically on criminalization cases, which prohibits the act allowed by collective law, although the national criminality is contrary to the collective law [13]. On the contrary, there is a less effect of collective law in the penalty area of criminality.

\subsubsection{Display Principle}

According to the Court of Justice of the European Community, the collective rules "have a direct impact. To make the rule of law, all national legislative text is nonexecutable". This rule is related with all collective law, irrespective of its shape. Regarding the Rome Convention, Articles 12 and 13 (that prevent the right of customs import and export) and 30 and 34 (prohibiting quantitative restrictions for import and export procedures with equivalent effects) cripples a large number of national regulations. From traditional male materials (L. 17 to L. 18), which emerged as today's material (L. 3323-1) of the Public Health Act, a propaganda has been defined regarding the benefit of some alcohol, which is different from whiskey. The Court of Justice of European Group has ruled that the French legislation is contrary to the principle of freedom of transit of goods, C. J. C. E., 10 July 1980. [10] It has been followed by the Court of Cassation, Crim., June 16, 1983 ; however, the materials were observed to be amended. For the derived collective law, the same principle has been observed as true. Thus, the European regulations deviate from previous national base. This is the release of one of the French importers of Italian wines, which were not relevant with French Act of 1941, but was compatible with European system, Crim., October 22, 1970.

\subsubsection{The Basis of Principle}

The interpretation of the principle of collective law usually raises the Highness (of Article 55) of the French Constitution. This argument has been made by the Criminal Chamber of the Court of Cassation in its earlier reference on 22 October 1969, regarding the import of Italian wines. This decision has explicitly referred to Article 55, under which "ratified agreements or treaties approved legally, since its application, a higher authority than laws, with the reservation of each agreement or treaty and applied by the other". But gradually, the separation of the Court of Cassation began to uphold Article (189), paragraph 2, of the Rome Convention, under which a collective system over the years is directly applicable in each Member State, Crim., January 7, 1972. Hence, the Rome Convention has not been considered as an unusual agreement, because its sovereignty has been restricted by signatory States over the national collective law, which constitutes an independent legal system. Due to different constitutions, the recourse to Article 55 could lead to a risk of causing a rift for the enforcement of collective law in various countries.[20] For this reason, it has been observed that the collective law seems to be imposed on States. Hence, the reason for operating in the hierarchy of 
sources of Penal Code has become clear, just under the constitution [4].

These arguments are very strong, so that the collective rules can be applied even to the national texts. Otherwise, the national authorities could demolish these rules on the basis of contrary provisions, after joining the group. The effect of International rules is not restricted to the impact on French Penal law and European Collective law, but also appears in the rules of European Convention on human rights and citizen. [45]

\subsection{European Convention for the Protection of Human Rights and Fundamental Freedoms and Additional Protocols (Human Rights) [14, 27, 29, 40, 43]}

With respect to the protection of human rights and freedoms, the proposed principle states- Remember the Convention, in first articles, a number of important principles, concerned with inevitably penal code.[43] Some of the examples include the right of confrontation and the right to not remand only in exceptional cases, or the right of foreigner to get an interpreter. This list has been extended after the law 31/12/1985, which allows the ratification of Protocol No. 7 to the Convention. This Protocol also placed an emphasis on other principles, such as the right to litigate on two degrees, and the right to compensation for individual victims of judicial error, the rule of non-retroactivity. Thus, it seems to have a reflection on European Convention on human rights and the Strasbourg judges European system requirements for human rights. Before a breach of Convention (Article 13) has been issued by the, it was expected that there is no particular objection in the Court of Cassation, which targets the parties regarding the international text. Thus, it is possible for the Supreme Court to either pursue, until they could provoke a breach of this provision. This shows the influence of European Convention on human rights and the jurisprudence of European Court of human rights on French law. However, this effect does not absolutely appear without limits.

\subsubsection{Effect of the Convention and European Justice French Penal Code}

The famous striking decision about baroom has been rendered on 5/12/1978, where trial judges an aggravating circumstance, while the accused has no information about the amendment of this prevention. [42] Hence, it was possible for the Court of Cassation to restrict their dependence on the texts of internal law, which are devoted to the principle of confrontation, particularly Article (427) of Code of Criminal Procedure. However, it has also been raised in Article 6, paragraph 3 of the European Convention on human rights, under which "every accused person has the right to be informed at earliest possible deadline, and in a detailed manner of nature and because of the accusation against him", Crim., January 7, 1979. Here, a number of decisions have been taken by the Court of Cassation, which can only be explained by European judiciary, which follows some legislative amendment. [42]. Hence, it can be reflected through interpretation, or through exclusion.

\subsubsection{Interpretation}

In most of the cases, French judiciary is required to interpret French law (or absence), in the light of European justice in Strasbourg. This is reflected in several areas, which include custody and wiretapping, independence of judicial part, and confront witnesses, in addition to the presumption of innocence. According to Article 5.3 of European Convention on human rights, "provisional detention is too long," and the application of this text adopted several decisions by the European Court of Human Rights to violate the principle of reasonable deadline, C. E. D. H., June 26, 1991. Sometimes, the Court of Cassation also condemned "remand", contrary to Article 5, paragraph 3 of European Convention on human rights, with the exception of complexity of the case- Crim., February 19 and 23, 1986- or the fault of Defender - Crim., June 12, 1997. The Act $30 / 12 / 1996$ has been introduced in the Code of Criminal Procedure (144-1). This Act claims that "preventive detention may not exceed a reasonable time for the gravity of the acts attributed to the arrested person and the complexity of necessary investigations to establish the truth," which is an echo of direct European law.

With regard to the legal wiretapping, France condemned because it has not been specified enough, C. E. C. H., stops, April 26, 1990. The French Court of Cassation came to the selections very quickly Crim., May 15, and July 17, 1990, and then came the legislator 10/7/1991 Article (100), followed by the French Code of Criminal Procedure.

On the other hand, the elimination of independence of judicial functions is very famous. According to the Article 6, paragraph 1 of European Convention on human rights, the accused has the right "impartial tribunal", which forces the inadmissibility of the exercise of same judge and several judicial functions in the same case. This seems to be resulted due to the European Court of human rights - Crim., January 10, 1996. In French law, Articles (49) and (253) of the Code of Criminal Procedure are some cases, where the combination has been forbidden. But in other cases, the Court of Cassation has accepted the principle of incompatibility of functions, on the basis of Article 6, Crim., February 21, 1996.

According to Article 6, paragraph 3, the accused has the right to face the witnesses guaranteed, as stated in European Convention on human rights and the jurisprudence of European Court of Human Rights, C. E. D. H., November 24, 1986. Furthermore, the Court of Cassation has begun to require trial judges to refuse the request of clear justification, and these judges raise no concern, due to lack of interest, Crim., January 12, 1989. On the contrary, it can be argued by Court that the accused had not asked for anything during investigation $[3,33]$.

If the presumption of innocence contained in Article 6, paragraph 2 of European Convention on human rights as a general rule, the European justice accepts some relaxation. In the case of customs duties, the European Court of human 
rights accepted that the legislation could contain some situations regarding the assumption of criminal responsibility, whether in fact or in law. As a result, these assumptions do not exceed certain limits, C. E. D. H., October 7, 1988.

\subsubsection{Exclusion}

It rarely happens that explicit national law is excluded by the Court of Cassation, which is not compatible with European law. Article (546) of French Code of criminal procedure provides that the Attorney General can appeal every verdict in infractions (while the right people pegged the preceding paragraphs of this article). Moreover, the French Court of Cassation ruled that this provision is contrary to the principle of equality of arms, as proposed by Article 6 of the European Convention on Human Rights, Crim., May 6 and 21, 1997.

The decisions, which exclude the criminalization text, should also be considered for the violation of European Convention on human rights. [7] The judge becomes lawmakers, for approval of criminalization texts. One of the examples include the "Cancel" criminality provided for in Article 2 of law 2/7/1931, and inhibitor of all news in investigation regarding the formation of a civil party (alleged personal), Crim., January 16, 2001. Here, the French legislator, officially at this time, should cancel this text, by issuing the law 9/3/2004. Thus, by monitoring the compatibility of domestic law of an agreement with Convention, the national re-judge the work of some laws.[28] But, the disadvantages of this behavior are that some European concepts of mystery, such as the phrase "necessary action in a democratic society", the judge's role extended to a degree that could lead to abuse. However, the European influence is not absolute without limits.

\subsubsection{Limit the Influence of European Convention on French Penal Code}

The French Court of Cassation does not go towards the application of European law in an absolute manner. But in this regard, one of the three cases includes the base of relative power of res judicata, and inappropriateness, and not to take a penalty (third branch).

Res Judicata. According to the Court of Cassation, the decisions of European Court of human rights, like the decisions of courts, do not enjoy relative authority to the rule of res judicata. Accordingly, it does not seem to have an impact on domestic law, and the decisions of French courts remains doable, and it condemned France for violating the European Convention on human rights, Crim., February 3, 1993. The theory of European law is the fact that the decisions of European Court of human rights is authorized, but not implemented (with the exception of "just satisfaction" or the amount of money that the European Court can impose on State Defender to claimed). The only obligation on the State is to take the Guide condemnation against this or any other consideration and amend its legislation or spending in the future. [11]

\subsubsection{Inappropriateness}

Majority of the provisions are confirmed by the Court of Cassation that French law is incompatible with the provisions of European Convention on human rights.[40] This procedure is often used in substantive criminal law. Moreover, the issue of objection adherent to the freedom of belief is a good example. According to the Article 9, it does not prevent the punishment of a citizen, who refuses to pay imposed tax as the expenses are rejected in the principle, Crim., May 19, 1983. Besides this, the article does not violate the pursuit of propaganda regarding smoke, Crim., February 21,1996 , or also from practicing the acts of obstruction of involuntary termination of pregnancy, Crim., January 31, 1996.

In this procedure, an inadequacy has also been emphasized, like Article 8 of European Convention on human rights, because the private life does not prevent Customs officers to conduct search and seizure, Crim., January 21, 1985, during screening documents, Crim., November 21, 1983. Such rules are observed to be extended due to the detention, which seems to be compatible with Article 5, paragraph 3 of European Convention on human rights. This Article provides that every arrested individual must be presented to the judge as soon as possible, Crim., July 3, 1980. Besides this, Protocol No. 7 of European Convention on human rights prevents the prosecution twice for the same Act, which did not prevent - according to the French Court of Cassation - Unlike the European Court of human rights.-, the sentencing of financial sanctions in parallel with the penalties imposed by the criminal judge, Crim., November 6, 1997.

Not to take the Penalty. It leaves the base violation of European Convention without penalty,[17] as is the case for busting the reasonable time requirement, which does not lead to the invalidity of measure, Crim., March 7, 1989. It can be said that European human rights law constitutes an important source of French criminal law,[33] even if France is sometimes condemned by European Court of human rights.[24] In addition, it has many French judges. Some of the passion of European Convention on human rights also became the judges of European Court of human rights, i.e. 7 in 1981, and 30 in 1990, and more than 100 decisions in recent years. European countries are not well keen to condemn it before the European Court of human rights, so acceleration has been observed to modify the legislation, in accordance with European Convention on human rights, which seems to be consistent with each other. Thus, it is clear that French penal legislator is no longer free to criminalization and criminal punishment.

\section{Conclusion}

Globalization, with respect to law, is generally classified as the worldwide progression of transnational discourses and legal structures. One of the most common challenges from the perspective of globalization is the traditional assumptions regarding international law. Taking into consideration the 
concept of globalization regarding criminal legislation, a model of French legislation has been considered to examine the outcomes. Through detailed analysis of previous studies, it has been identified that the limitation of penalties has not been restricted to French legislation, but the situation is same in all European countries like Germany, Spain and others, which led to the creation of a European criminal legislation. And if we know that French law applies overseas, and many have been affected by the criminal legislation in Africa, Asia and Europe, it can be imagined that how far is the application of international principles in different parts of the world. Hence, the principles of respect for human rights had taken on a global dimension, which required all States to ensure the rights in domestic legislation, whether European or not. From the foregoing, it has been concluded that an access is required to comparative legislation, making legislation easier to ensure respect for human rights, and not to wait for the dictates of powerful States to weak States. It is imperative to find an Arab Court of human rights condemns violations of those rights in Arabic countries, to help them modify their legislation, in accordance with respect to the inherent rights.

\section{References}

[1] Al-Refo, M. Y. D., \& Faqir, R. S. (2016) From Legal Translation to Legal Globalization: Globalization of Criminal Laws to Counter Global Crimes. International Journal of Social Science and Humanity 6 (4), $275 . \quad$ Doi: 10.7763/IJSSH.2016. V6.657.

[2] Alter, K. J. (2012) The global spread of European style international courts. West European Politics 35 (1), 135-154. Doi. org/10.1080/01402382.2012.631318.

[3] Berger V (1998) Case Law of the C. E. D. H.: 6th Ed., preface L. Pettiti.

[4] Bigay J (1972) Community Law and Criminal Law. R. T. D. Eur., p. 733.

[5] Bonichot J (1988) Community Law and Criminal Law, RSC: p. 581.

[6] Bore J (1989) The difficult meeting of French Criminal Law and EU Law, Vitu Mixtures: p. 25.

[7] Borricand J (1999) The influence of the French Conv E. D. H. on criminal jurisprudence. Current: Issues in Criminal Science XII, Faculty of Law of Aix-Marseille, p. 81.

[8] Bouloc B (1992) The influence of Community Law over Domestic Criminal Law”, Levasseur Mixtures: p. 103.

[9] Cavadino, M., \& Dignan, J. (2006) Penal policy and political economy. Criminology and Criminal Justice. 6 (4), 435-456. Doi: $10.1177 / 1748895806068581$.

[10] Cohen-Jonathan G (1995) Some considerations on the authority of the judgments of the C. E. D. H., Free amicorum M. A: Eissen, Bruylant and L. G. D. J, p. 39s.

[11] Debove M (1995) The renewal of French repressive norms by European law: thèse dactyl, Paris II.

[12] Decocq A (1981) The conflict between the Community regulation and the domestic criminal rule. In Community Law and Criminal Law: Parma, p. 3.

[13] Delmas-Marty M (1987) European Union and Criminal Law: The notebooks of European Law, p. 607.

[14] Delmas-Marty M (1989) Criminal law and rule of law according to Conv. E. D. H.: Vitu Mixtures, p. 151.

[15] Delmas-Marty M (1997) European Union and Criminal Law: European law books, p. 613.

[16] Dhavernas O (1997) Obstruction of abortion, Sketch stock: RSC, p. 821.

[17] Fabre M (1998) The right to a fair trial, la case study on Article 681: Conv. E. D. H. J. C. P, I. 157.

[18] Huet A (1997) Criminal Law: In Community Law Encyclopedia.

[19] Jeantet C (1975) The court of cassation and the community legal order. J. C. P. I. 2743, 18.

[20] Jeantet F (1975) The court of cassation and the community legal order J. C. P., I. 2743.

[21] Joubert, C. (2005) Judicial control of foreign evidence in comparative perspective. Rozenberg Publishers.

[22] Koering-Joulin R and Seuvic JF (1998) Fundamental Rights and Criminal Law: A. J. D. A, p. 106.

[23] Levasseur G (1998) International Protection of Human Rights and la French Criminal Procedure, Mélanges R. Gassin, I, p. 139s; The interpretation of the European Convention on Human Rights (under the direction of F. SUDRE), conference proceedings 13 and 14 March 1998 organized by the Institute of European Law of Human Rights. Montpellier I, Bruylant: Brussels.

[24] Marguenaud JP (2000). The drift of the French Criminal Proceedings by European Requirements D: chron, p. 249.

[25] Masse M (1996) The influence of Community law over French criminal law: RSC, p. 943.

[26] Masse M (1996) The influence of Community law over French criminal law: RSC, p. 335s.

[27] Mayer D (1992) Evolution of the attitude of the criminal division in respect of la conv. E. D. H: Levasseur Mixtures, p. 239.

[28] Mayer D (2001) Towards a legislature controlled by the criminal court? D., chron., p. 1643.

[29] Merle R (1981) Conv. E. D. H. and French criminal justice: D., chron, p. 227.

[30] Mirela, P. I. A., \& Lavinia, O. (2011). Homosexuality, Religion, Law. AGORA Int'l J. Jurid. Sci., cxxxiii.

[31] Nwebo, O., \& Ubah, C. (2015) Globalization of Crime: Problems and Challenges for World Peace and Security. International Journal of Liberal Arts and Science: 3 (2), 91104.

[32] Penal Code (n. d.) Légifrance, the public service access to law. Retrieved from: https://www.legifrance.gouv.fr/content/download/1957/.../Cod e_33.pdf. 
[33] Pettiti L and Koering-Joulin R (n. d.) Quarterly Chronicle the RSC. Pradel J (1990) The Conv. E. D. H. and French Criminal Trial: Harmony or Conflict? (p. 354). Legal Review Themis: Montreal.

[34] Pradel J (1993) Arrest and detention under the particular angle of the Conv. E. D. H. Symposium of the International Penal and Penitentiary Foundation, Neuchatel, October 1992, Foundation Publications.

[35] Pradel J (1993) The conduct of criminal proceedings, in French law and la Conv. E. D. H. Symposium held in Montpellier February 1993, Publications of the Institute of European Law of Human Rights, Montpellier.

[36] Pradel J (1993) The impact of the jurisprudence of the Conv. E. D. H. the French criminal law. Symposium organized by the Faculty of Law Poitiers and of Nimègue, May 1991, Publications of the Faculty of Law Poitiers, P. U. F.

[37] Pradel J (2000) Towards a Globalization of Criminal Law. L. G. D. J.
[38] Pradel J (2002) Comparative Criminal Law. Dalloz.

[39] Pradel J and Corstens G (2002). European Criminal Law. Dalloz.

[40] Renucci JF (2007) Treaty of Law in Europe Human Rights, L. G. D. J.

[41] Robert JH (1992) The Criminalization of the National Legislature by reference to Future EU Regulations. Levasseur Mixtures, p. 165.

[42] Soyer JC and De Salvia M (1982) The Supranational Individual Application Manual, L. G. D. J.

[43] Sudre F (1995) International and European Law of Human Rights (2nd Ed). P. U. F.

[44] Tillement G (2003) The review of the necessity of offenses by the criminal court Dr. Pénal, chron. 34.

[45] Work of the European Conference on 26 and 27 March 1991 on the theme "criminal trial and human rights, Towards a European awareness", P. U. F., 1992. 